\title{
Kualitas Daging Broiler yang Dijual di Pasar Tradisional Kecamatan Denpasar Selatan
}

\author{
(THE QUALITY OF BROILER CARCASSES SOLD IN TRADITIONAL MARKETS \\ OF SOUTH DENPASAR SUBDISTRICT)
}

\author{
Suci Wulandari ${ }^{1 *}$, Ida Bagus Ngurah Swacita ${ }^{1}$, Mas Djoko Rudyanto ${ }^{1}$ \\ ${ }^{1}$ Departemen Pencegahan Penyakit, Laboratorium Kesehatan Masyarakat Veteriner, Fakultas \\ Kedokteran Hewan, Universitas Udayana, Jln. PB Sudirman Denpasar-Bali \\ *Email: swulandaari@gmail.com
}

\begin{abstract}
Abstrak
Penelitian ini bertujuan untuk mengevaluasi kualitas karkas broiler yang dijual di pasar tradisional Kecamatan Denpasar Selatan. Pengambilan sampel dilakukan di empat pasar tradisional dan masingmasing pasar diambil tiga pedagang dengan ulangan sebanyak enam kali. Parameter yang diamati meliputi nilai daya ikat air (DIA), nilai $\mathrm{pH}$, dan susut masak. Data hasil pengukuran dianalisis dengan uji ANOVA dan apabila terdapat perbedaan nyata $(\mathrm{P}<0,05)$, dilanjutkan dengan Duncan's new Multiple Range Test. Hasil penelitian menunjukan bahwa uji pH dan Daya Ikat Air (DIA) daging broiler pada keempat pasar di Kecamatan Denpasar Selatan tidak berbeda nyata $(\mathrm{P}>0,05)$. Sedangkan, susut masak menunjukkan hasil yang berbeda nyata $(\mathrm{P}<0,05)$ pada setiap pasar. Berdasarkan hasil penelitian maka dapat disimpulkan bahwa kualitas daging broiler yang dijual di pasar tradisional Kecamatan Denpasar Selatan masih baik dan layak dikonsumsi.
\end{abstract}

Kata kunci: Kualitas; broiler; pH; daya ikat air; susut masak; pasar.

\begin{abstract}
This study aims to evaluate the quality of broiler carcasses that are sold in traditional markets of South Denpasar District. Sampling was conducted in four traditional markets and each market was picked up by three sellers with six repetitions. The parameters observed included water holding capacity (WHC), $\mathrm{pH}$ value, and cooking loss. The measurement data were analyzed by ANOVA test and if there was a significant difference $(\mathrm{P}<0.05)$ then will be continued with Duncan's New Multiple Range Test. The results showed that $\mathrm{pH}$ and Water Holding Capacity (WHC) test of broiler meat in all four markets in South Denpasar district was not significantly different $(\mathrm{P}>0,05)$. Meanwhile, the cooking loss showed significantly different results $(\mathrm{P}<0.05)$ in each market. Based on the research, it can be concluded that the quality of broiler meat sold in the traditional market of South Denpasar District is still good and feasible to be consumed.
\end{abstract}

Keywords: Quality; broiler; pH; water holding capacity; cooking loss; market.

\section{PENDAHULUAN}

Daging broiler merupakan salah satu sumber pangan hewani yang memiliki kandungan gizi tinggi, lengkap dan seimbang, namun mudah mengalami kerusakan (Afrianti et al., 2013). Kerusakan pada daging dapat disebabkan karena adanya benturan fisik, perubahan kimia, dan aktivitas mikroba yang nantinya dapat menurunkan kualitas daging (Soeparno, 2009). Kerusakan daging ayam lebih banyak diakibatkan oleh adanya pertumbuhan mikroba yang berasal dari ternak dan pencemaran dari lingkungan pada saat pemotongan maupun selama pemasaran (Hajrawati et al., 2016).

Pasar tradisional merupakan salah satu tempat penjualan daging ayam. Secara umum kondisi pasar tradisional memiliki sanitasi yang kurang baik, sehingga kemungkinan terjadinya kontaminasi menjadi lebih tinggi. Hal ini dikarenakan daging broiler yang dijual ditempatkan pada kondisi terbuka dengan menempatkan daging di atas meja tanpa 
adanya pengaturan suhu sehingga akan berpengaruh terhadap kualitas daging. Leestyawati (2005) menyatakan bahwa daging broiler yang beredar di pasar wilayah Bali sebagian besar masih belum memenuhi Standar Nasional Indonesia (SNI No. 01-6366-2000). Hasil pengamatan menunjukkan bahwa di beberapa pasar kecamatan Denpasar Selatan masih sering ditemukan daging ayam yang memar, perdarahan dibagianbagian tertentu serta peralatan penjualan daging seperti meja tempat menggelar daging, pisau, talenan, timbangan dan peralatan lain masih jauh dari kategori bersih. Selain itu, penjualan daging ayam yang berasal dari ayam tiren (mati kemarin) dan berasal dari proses penyembelihan yang kurang baik saat ini juga masih terjadi (Swari et al., 2019).

Mengingat masih adanya peredaran daging ayam yang tidak berkualitas dan upaya untuk melindungi masyarakat dari konsumsi daging yang tidak sehat, maka perlu dilakukan penelitian evaluasi kualitas daging broiler di beberapa pasar tradisional wilayah Denpasar Selatan melalui uji $\mathrm{pH}$, daya ikat air, dan susut masak.

\section{METODE PENELITIAN}

Objek penelitian yang digunakan adalah daging broiler bagian dada sebanyak 72 sampel. Sampel tersebut diperoleh dari empat pasar tradisional di kecamatan Denpasar Selatan yaitu: Pasar Sudha Merta, Pasar I Made Putra, Pasar Kertha Boga Pemogan, dan Pasar Nyanggelan. Dari masing-masing pasar diambil tiga pedagang dengan jumlah sampel dari masing-masing pedagang seberat 100 gram. Penelitian diulang sebanyak enam kali dengan interval setiap hari sekali. Penelitian ini menggunakan Rancangan Acak Kelompok (RAK) dengan empat perlakuan berdasarkan tempat pengambilan sampel.

Pengukuran nilai $\mathrm{pH}$ karkas dilakukan dengan menggunakan $\mathrm{pH}$ meter sesuai acuan menurut Association Official
Analitycal Chemistry (AOAC) (2005). Pengukuran Daya Ikat Air dilakukan dengan cara penekanan (metode Hamm) sesuai dengan acuan menurut Soeparno (2009). Pengukuran susut masak (\%) dilakukan dengan mengurangkan berat sebelum dan sesudah dimasak dibagi berat awal dan dipersenkan (Salakova et al., 2009). Kemudian data yang diperoleh dari uji $\mathrm{pH}$, daya ikat air, dan susut masak dianalisis dengan ANOVA, jika terdapat pengaruh yang nyata dilanjutkan dengan uji Duncan Multiple Range Test (DMRT).

\section{HASIL DAN PEMBAHASAN}

Hasil uji statistika kualitas daging broiler di pasar Kecamatan Denpasar Selatan melalui uji $\mathrm{pH}$ dan daya ikat air (DIA), menunjukkan hasil tidak berbeda nyata $(\mathrm{P}>0,05)$. Sedangkan pada susut masak menunjukkan hasil berbeda nyata $(\mathrm{P}<0,05)$.

\section{Nilai pH}

Hasil analisis data menggunakan sidik ragam (ANOVA) menunjukkan bahwa nilai $\mathrm{pH}$ tidak berbeda nyata $(\mathrm{P}>0,05)$ pada daging yang dijual di keempat pasar tersebut (Tabel 1). Rataan nilai $\mathrm{pH}$ yang diperoleh dalam penelitian ini adalah 5,73, nilai rataan $\mathrm{pH}$ tersebut tergolong normal dan menunjukkan bahwa kualitas daging masih dalam kategori baik. Nilai $\mathrm{pH}$ terbentuk akibat timbunan asam laktat hasil perombakan glikogen. Perbedaan nilai $\mathrm{pH}$ disebabkan oleh perbedaan cadangan glikogen yang dapat diduga dari perbedaan bobot badan (Pragati et al., 2007). Suradi (2006) mengemukakan bahwa $\mathrm{pH}$ daging setelah pemotongan ternak dipengaruhi oleh ketersediaan asam laktat di dalam otot. Ketersediaan asam laktat ini dipengaruhi oleh kandungan glikogen, dan kandungan glikogen dipengaruhi oleh penanganan ternak sebelum dipotong. Proses perombakan glikogen menjadi asam laktat pada saat rigor mortis terjadi selama 6-8 jam dengan $\mathrm{pH}$ ultimat daging normal berkisar antara 5.7-5.8 (Zhuang dan Savage 2012; Van Laack et al., 2000). 
Tabel 1. Rataan penghitungan nilai $\mathrm{pH}$ daging broiler dari pasar tradisional di Kecamatan Denpasar Selatan

\begin{tabular}{lcc}
\hline Nama Pasar & Nilai $\mathrm{pH} \pm \mathrm{SD}$ & $\begin{array}{c}\text { Signifikansi } \\
(\mathrm{P}>0,05)\end{array}$ \\
\hline I Made Putra & $5,69 \pm 0,10$ & $\mathrm{a}$ \\
Nyanggelan & $5,69 \pm 0,12$ & $\mathrm{a}$ \\
Kertha Boga Pemogan & $5,77 \pm 0,14$ & $\mathrm{a}$ \\
Sudha Merta & $5,75 \pm 0,13$ & $\mathrm{a}$ \\
\hline Nilai Signifikansi & & 0,152 \\
\hline
\end{tabular}

Keterangan: Huruf yang sama ke arah kolom menunjukkan tidak berbeda nyata $(\mathrm{P}>0,05)$. Nilai $\mathrm{pH}$ daging ayam broiler yang dijual di keempat pasar tradisional tidak berbeda nyata $(\mathrm{P}>0,05)$.

\section{Daya Ikat Air (DIA)}

Hasil analisis data menggunakan sidik ragam (ANOVA) menunjukkan nilai daya ikat air tidak berbeda nyata $(\mathrm{P}>0,05)$ pada daging yang dijual di masing-masing pasar (Tabel 2). Rataan nilai daya ikat air (DIA) yang diperoleh pada penelitian ini adalah $72,80 \%$. Nilai tersebut tergolong tinggi. Nilai DIA yang tinggi menandakan kualitas daging yang baik. Menurut Ockerman (1983), nilai daya ikat air daging dipengaruhi oleh kandungan protein dan karbohidrat daging, kandungan protein daging yang tinggi akan diikuti dengan semakin tingginya daya ikat air. Daging yang masih baik, struktur proteinnya akan mengikat ketiga komponen air yang terdapat pada daging yaitu air bebas (free water), air terikat erat (tight water), dan air yang tidak bergerak (immobilized water) dengan baik. Keutuhan protein yang baik menyebabkan meningkatnya kemampuan mengikat air daging. Sebaliknya bila daging mulai rusak, maka struktur proteinnya akan mengalami dekomposisi dan dipecah menjadi peptida, pepton, asam amino dan seterusnya sehingga air yang ada di dalam daging akan keluar yang menyebabkan DIA akan menurun (Suardana dan Swacita, 2009). Selain itu, otot dengan kandungan lemak intramuskuler tinggi cenderung memperlihatkan DIA yang tinggi. Lemak intramuskuler akan melonggarkan mikrostruktur daging, sehingga memberi lebih banyak kesempatan kepada protein daging untuk mengikat air (Joo et al., 2013).

Tabel 2. Rataan penghitungan nilai Daya Ikat Air daging broiler dari pasar tradisional di Kecamatan Denpasar Selatan

\begin{tabular}{llc}
\hline Nama Pasar & DIA $(\%) \pm$ SD & Signifikansi $(\mathrm{P}>0,05)$ \\
\hline I Made Putra & $73,36 \pm 3,29$ & $\mathrm{a}$ \\
Nyanggelan & $71,56 \pm 5,07$ & $\mathrm{a}$ \\
Kertha Boga Pemogan & $73,05 \pm 3,31$ & $\mathrm{a}$ \\
Sudha Merta & $73,23 \pm 3,97$ & $\mathrm{a}$ \\
\hline Nilai Signifikansi & & 0,504 \\
\hline
\end{tabular}

Keterangan: Huruf yang sama ke arah kolom menunjukkan tidak berbeda nyata $(\mathrm{P}>0,05)$. DIA daging broiler yang dijual di keempat pasar tradisional tidak berbeda nyata $(\mathrm{P}>0,05)$

\section{Susut masak}

Hasil analisis data menggunakan sidik ragam (ANOVA) menunjukkan bahwa nilai susut masak berbeda nyata $(\mathrm{P}<0,05)$ pada daging broiler yang dijual di masingmasing pasar tersebut (Tabel 3). Hasil susut masak yang berbeda nyata $(\mathrm{P}<0,05)$ pada setiap pasar (perlakuan), dilanjutkan dengan uji Duncan untuk mengetahui perbedaan antara pasar tersebut.

Hasil uji Duncan menunjukkan rataan nilai susut masak daging ayam broiler 
antara Pasar I Made Putra tidak berbeda nyata $(\mathrm{P}>0,05)$ dengan Pasar Nyanggelan, Pasar Kertha Boga, dan Pasar Sudha Merta. Sedangkan Pasar Kertha Boga Pemogan berbeda nyata $(\mathrm{P}<0,05)$ dengan Pasar Nyanggelan dan Pasar Sudha Merta.

Rataan nilai susut masak daging ayam broiler dalam penelitian ini adalah 33,93\%, nilai tersebut masih dalam kisaran normal daging broiler yaitu antara 30-37\% (Raj, 2003). Daging dengan susut masak rendah mempunyai kualias relatif lebih baik daripada daging dengan susut masak lebih besar. Hal ini dikarenakan kehilangan nutrisi selama pemasakan akan lebih sedikit (Soeparno, 2009). Menurut Dewayani et al. (2015), susut masak daging dipengaruhi oleh nilai $\mathrm{pH}$, panjang sarkomer serabut otot, panjang potongan serabut otot, status kontraksi miofibril, ukuran dan berat sampel, penampang melintang daging, pemanasan, bangsa terkait lemak daging, umur, dan konsumsi energi dalam pakan.

Tabel 3. Rataan penghitungan nilai susut masak daging broiler dari pasar tradisional di Kecamatan Denpasar Selatan.

\begin{tabular}{llc}
\hline Nama Pasar & $\begin{array}{l}\text { Susut Masak }(\%) \pm \\
\text { SD }\end{array}$ & $\begin{array}{c}\text { Signifikansi } \\
(\mathrm{P}<0,05)\end{array}$ \\
\hline I Made Putra & $33,48 \pm 3,31$ & $\mathrm{ab}$ \\
Nyanggelan & $34,71 \pm 2,03$ & $\mathrm{~b}$ \\
Kertha Boga Pemogan & $32,01 \pm 3,91$ & $\mathrm{a}$ \\
Sudha Merta & $35,53 \pm 3,41$ & $\mathrm{~b}$ \\
\hline Nilai Signifikansi & & 0,011
\end{tabular}

Keterangan: Huruf yang sama ke arah kolom menunjukkan tidak berbeda nyata $(\mathrm{P}>0,05)$, sebaliknya huruf yang berbeda ke arah kolom menunjukkan berbeda nyata $(\mathrm{P}<0,05)$.

\section{SIMPULAN DAN SARAN}

\section{Simpulan}

Berdasarkan hasil penelitian maka dapat disimpulkan bahwa rataan nilai $\mathrm{pH}$ $(5,73)$, Daya Ikat Air $(72,80 \%)$, susut masak $(33,93 \%)$ daging broiler yang dijual di Pasar tradisional Kecamatan Denpasar Selatan masih dalam batas normal dan kualitasnya masih tergolong baik.

\section{Saran}

Perlu dilakukan pembinaan dan pengawasan terhadap penyediaan daging ayam di pasar tradisional oleh pihak yang berwenang serta pedagang daging broiler diharapkan untuk menjaga higiene dan sanitasi lingkungan.

\section{UCAPAN TERIMA KASIH}

Penulis mengucapkan terima kasih kepada pimpinan dan staff Laboratorium Kesehatan Masyarakat Veteriner Fakultas Kedokteran Hewan Universitas Udayana serta pimpinan dan staff Balai Karantina Pertanian Kelas I Denpasar yang telah memberikan fasilitas dalam penelitian ini serta semua pihak yang telah membantu dalam penyelesaian penelitian ini.

\section{DAFTAR PUSTAKA}

Afrianti M, Dwiloka B, Setiani BE. 2013. Total bakteri, $\mathrm{pH}$ dan kadar air daging ayam broiler setelah direndam dengan ekstrak daun senduduk (Malestona malabathricum L.) selama masa simpan. J. Pangan dan Gizi. 04(7): 4956.

Association Official Analitycal Chemistry (AOAC). 2005. Official Method of Analysis. $18^{\text {th }}$ Ed. Maryland (US): AOAC International, Washington D.C.

Dewayani RE, Halim N, Osfar S. 2015. Pengaruh penggunaan onggok dan ampas tahu terfermentasi Mix Culture Aspergillus Niger dan Rhizopus Oligosporus sebagai pengganti jagung dalam pakan terhadap kualitas fisik daging ayam pedaging. J. Ilmu dan Teknol. Hasil Ternak, 10(1): 9-17.

Hajrawati, Fadliah W, Arief II. 2016. Kualitas fisik, mikrobiologis, dan 
organoleptik daging ayam broiler pada pasar tradisional di Bogor. J. Ilmu Produksi dan Teknol. Hasil Peternakan, 04(3): 386-389.

Joo ST, Kim GD, Hwang YH, Ryu YC. 2013. Control of fresh meat quality through manipulation of muscle fiber characteristics. Meat Sci., 95(4): 828836.

Leestyawati NW. 2005. Upaya peningkatan keamanan daging ayam di Bali. Lokakarya Nasional Keamanan Pangan Produk Peternakan. Puslitabangtan. Pp. 108-111.

Ockerman. 1983. Chemistry of Meat Tissue. $10^{\text {th }}$ Ed. Departmen of Animal Science. The Ohio State University and The Ohio Agricultural Research and Development Center.

Pragati H, Kondaiah N, Anjancyulu ASR, Saikia P. 2007. Meat yield and sensory quality of products from broilers of three live weight groups. Indian $J$. Anim. Sci., 77: 613-615.

Raj ABM. 2003. Effects of stunning and slaughter method on carcass and meat quality. Poult. Meat Sci., 25: 246-247.
Salakova A, Strakova E, Valkova V, Buchtova H, Steinhaserova I. 2009. Quality indicator of chicken broiler raw and cooked meat depending on their sex. Aacta Vet. 78: 497-504.

Soeparno. 2009. Ilmu dan Teknologi Daging. 5 Ed. Gadjah Mada University Press.Yogyakarta.

Suardana IW, Swacita IBN. 2009. Higiene Makanan. 1 Ed. Udayana University Press. Denpasar.

Suradi K. 2006. Perubahan sifat fisik daging ayam broiler. post mortem selama peyimpanan temperatur ruang. J. Ilmu Ternak, 6(1): 23-27.

Swari LPP, Agustina KK, Swacita IBN, Suada IK. 2019. Deteksi penjualan daging ayam mati (tiren) di empat pasar tradisional Kota Denpasar. Buletin Vet. Udayana. 11(2): 143-150.

van Laack RLJ, Liu CH, Smith MO, Loveday, HD. 2000. Characteristics of pale, soft, exudative broiler breast meat. Poult. Sci., 79: 1057-1061.

Zhuang H, Savage EM. 2012. Effect of fillet weight on sensory descriptive flavor and texture profiles of broiler breast meat. Poult. Sci., 91: 1695-1702. 